\title{
Influence of parent material on the contents and distribution of $B$ and Zn in upland soils of Bauchi State, Nigeria
}

\author{
*S. Mustapha; A. S. Fagam \\ Crop Production Programme, Abubakar Tafawa Balewa University, P.M.B. 0248, Bauchi, Nigeria
}

Received 22 April 2006; revised 15 November 2006; accepted 7 March 2007

\begin{abstract}
A study was conducted to determine the influence of parent material on the contents and distribution of boron and zinc in soils of Bauchi State, Nigeria. Fourty nine, 30, and 20 top $0-30 \mathrm{~cm}$ soil samples developed from basement complex rock, Kerri-Kerri Formation and Chad Formation, respectively, were collected and analysed using standard laboratory procedures. Results obtained indicate that parent material influenced Zn but not B contents in the soils. Generally, both B and $\mathrm{Zn}$ varied widely $(\mathrm{CV}>30 \%)$ between locations in the State, irrespective of the parent material. Organic carbon significantly $(\mathrm{P}<0.01)$ and negatively correlated with $\mathrm{Zn}$ in soils from $\mathrm{BCR}(\mathrm{r}=-0.410)$ and CF $(r=-0.563)$ and positively with B in soils developed from KKF $(r=0.471)$ and CF $(r=0.345)$. With means of 0.41 and $1.46 \mathrm{mgkg}^{-1}$ for $\mathrm{B}$ and $\mathrm{Zn}$ respectively, their contents are considered adequate for crop growth. Crops grown on soils in some localized areas identified with values below the critical limits for these micronutrients may, however, benefit from their application.
\end{abstract}

Key words: Parent material, distribution, B, Zn, upland soils

\section{INTRODUCTION}

The importance of micronutrients in general and boron and zinc in particular, in plant nutrition cannot be overemphasized. This is so especially against the background that many Nigerian soils are very acidic and may, therefore, contain low to excessive or even toxic amounts of these available micronutrients, which could hamper crop production (Amalu, et al., 2001). Boron deficiencies have been reported to be most particularly prevalent in sandy and highly leached acid soils low in organic matter (Abdu, et al., 2006) and in soils derived from igneous origin (Burridge and Ahn, 1970). Conversely, most soils derived from marine sediments are reported (Bowen and Kratky, 1983) to be rich in boron. Zinc, on the other hand, has been shown to be deficient in some soils in Bauchi State (Mustapha and Singh, 2003). The human population in Nigeria and indeed in Bauchi State is on a rapid increase. This translates to greater need for the efficient utilization of the land to produce crops to feed the ever-increasing human and animal populations. To achieve this goal, there is a pressing need for the evaluation of the soil nutrient status, more especially, the micronutrients. The need for this evaluation is further necessitated by the

ه*Corresponding Author Email: shafiumusty@yahoo.com Tel./Fax:234-8060866612 realization that soils in Bauchi State are principally formed on parent materials that are known to play significant roles in the determination of the contents and distribution of many nutrient elements (Mustapha, et al., 2002). It was against this backdrop that a study was conducted to evaluate the content and distribution of B and $\mathrm{Zn}$ in soils as influenced by the three parent materials found in Bauchi State, Nigeria, namely: basement complex rocks, Kerri-Kerri and Chad formations.

\section{MATERIALS AND METHODS}

The study was conducted in Bauchi State (Latitudes 9 $32^{\prime}-12^{\circ} 33^{\prime} \mathrm{N}$; Longitudes $8^{\circ} 50^{\prime}-11^{\circ} 01^{\prime} \mathrm{E}$ ), Nigeria from October to December, 2006. Lithologically, soils in the State are formed from Basement Complex rock (BCR) and the Sedimentary Rocks comprising the Kerri-Kerri (KKF) and the Chad (CF) formations. The BCR covers most part of the State. A total of 49, 30, and 20 top 0$30 \mathrm{~cm}$ representative soil samples were respectively collected from the BCR, KKF and CF, making a total of 99 samples. Each soil sample was separately dried in air, ground using porcelain pestle and mortar, and passed through a 2-mm sieve. The sieved soil samples were used for all laboratory analyses. Particle-size 
analysis was performed by the Bouyoucos hydrometer method, soil pH was measured in 1:1 soil/water suspension, while organic carbon was determined by the Walkley-Black method. Available B and Zn were respectively extracted from the soils by the hot water extraction and $0.1 \mathrm{MHCl}$ methods. The procedures followed were as described by Page, et al. (1982). Data obtained were subjected to simple descriptive statistics (including means and coefficient of variation), analysis of variance (ANOVA) and correlation analysis (Harry and Steven, 1995). Means that were statistically significant were separated using the Least Significant Difference (L.S.D.).

\section{RESULTS}

Particle-size distribution, $\mathrm{pH}$ and organic carbon status

Table 1 shows the particle-size distribution, $\mathrm{pH}$ and organic carbon contents in soils developed from the three parent materials, namely: BCR, KKF and CF in Bauchi State, Nigeria. The sand and silt contents in soils from the three parent materials did not significantly $(\mathrm{P}=0.05)$ vary. In soils developed from BCR and KKF, however, sand fraction was somewhat uniformly distributed $(\mathrm{CV}<15 \%)$ as opposed to the wide variability $(\mathrm{CV}=30.9 \%)$ observed in soils from the CF. The clay content varied significantly $(\mathrm{P}=0.05)$ following the pattern: $\mathrm{CF}>\mathrm{BCR}>\mathrm{KKF}$. With $\mathrm{CV}>15 \%$ in each case for all the soils considered, its distribution could be said to be wide. The overall mean $\mathrm{pH}$ (in water) was 6.0 with a $\mathrm{CV}<10 \%$. Organic carbon content significantly $(\mathrm{P}=0.001)$ varied in the soils from the three parent materials considered in this study. The soils of CF origin had statistically highest organic carbon (matter) (mean $=9.4$ $\mathrm{gk} / \mathrm{g}$ ) than those from BCR (mean $=5.3 \mathrm{~g} / \mathrm{kg}$ ) and KKF (mean $=6.0 \mathrm{~g} / \mathrm{kg}$ ), which were at par. The distribution of organic carbon was more or less uniform $(\mathrm{CV}<10 \%)$ in soils developed from KKF but varied widely (CV>30\%) in soils from BCR and CF.

\section{Zn and $B$ status}

Table 2 shows the distribution of $\mathrm{Zn}$ and $\mathrm{B}$ in soils developed from the three parent materials studied. The results indicate that parent material significantly $(\mathrm{P}=0.05)$ influenced the distribution of $\mathrm{Zn}$; with soils developed from KKF having significantly highest amounts. It is noteworthy, however, that with CV (in \%) of 34.5, 61.0 and 46.3, respectively for BCR, KKF and CF, Zn contents varied widely in the soils in each parent material and generally in the State $(\mathrm{CV}=61.0 \%)$. The type of parent material did not significantly $(\mathrm{P}=0.05)$ influence the distribution of $\mathrm{B}$ in the soils studied (Table 2). Though it varied within wide limits $(\mathrm{CV}=41.1 \%$; range $=0.13-0.80$ $\mathrm{mgk} / \mathrm{g}$ ), B contents were within the optimum 0.1-0.5ppm level reported by Amalu et al. (2001) for optimum crop growth.

\section{Correlations}

Correlations among some of the soil physico-chemical properties and between them and $\mathrm{Zn}$ and B contents are presented in Table 3. Organic carbon significantly $(\mathrm{P}<0.01)$ and negatively correlated with $\mathrm{Zn}$ in soils developed from BCR $(r=-0.410)$ and CF $(r=-0.563)$.

Table 1: Some physico-chemical properties of the top 0-30cm soils developed from BCR, KKF and CF in Bauchi State

\begin{tabular}{|c|c|c|c|c|c|}
\hline & Sand & $\begin{array}{l}\text { Silty } \\
(\%)\end{array}$ & Clay & $\begin{array}{l}\mathrm{pH} \\
\text { (in water) }\end{array}$ & $\begin{array}{l}\text { Organic C } \\
(\mathrm{g} / \mathrm{kg})\end{array}$ \\
\hline \multicolumn{6}{|c|}{ Basement complex rock } \\
\hline Range & $57.0-82.0$ & $7.0-30.0$ & $8.0-26.0$ & $5.22-6.44$ & $3.6-14.0$ \\
\hline Mean & 69.3 & 16.3 & 14.2 & 5.98 & 5.3 \\
\hline CV (\%) & 11.1 & 44.1 & 29.1 & 4.9 & 38.8 \\
\hline \multicolumn{6}{|c|}{ Kerri-Kerri formation } \\
\hline Range & $53.0-83.0$ & $5.0-31.0$ & $5.0-21.0$ & $5.30-6.34$ & $4.2-7.8$ \\
\hline Mean & 67.2 & 18.6 & 13.9 & 6.01 & 6.0 \\
\hline CV (\%) & 14.2 & 36.5 & 30.8 & 3.9 & 7.9 \\
\hline \multicolumn{6}{|c|}{ Chad formation } \\
\hline Range & $17.0-87.0$ & $30.0-48.0$ & $8.0-35.0$ & $5.34-6.56$ & $4.4-14.8$ \\
\hline Mean & 65.7 & 16.9 & 17.5 & 5.89 & 9.4 \\
\hline CV (\%) & 30.9 & 75.8 & 47.2 & 5.0 & 33.8 \\
\hline Overall mean & 67.6 & 17.6 & 14.6 & 6.0 & 6.8 \\
\hline L.S. & - & - & * & - & $* * *$ \\
\hline LSD(parent material; $\mathrm{P}=0.05$ ) & NS & NS & 1.46 & NS & 0.77 \\
\hline
\end{tabular}

NS: Not significant; L.S. $=$ Level of significance; $*$ and $* * *=$ significant at $\mathrm{P}=0.05$ and 0.001 , respectively

$\mathrm{BCR}=$ Basement complex rock; KKF = Kerri-kerri Formation; CF = Chad Formation 
Though also negatively correlated with $\mathrm{Zn}$ in soils developed on KKF ( $r=-0.365)$, the association was not significant $(\mathrm{P}=0.05)$. It is equally noteworthy that the association between clay and $\mathrm{Zn}$ contents was significant $(\mathrm{P}<0.05)$ and positive in soils developed from BCR $(r=0.440)$ and $\operatorname{KKF}(r=0.539)$ but negative $(r=-0.460)$ in soils developed from CF. Silt did not significantly $(\mathrm{P}=0.05)$ correlate with $\mathrm{Zn}$ in soils from CF, but it did, positively, in soils from $\operatorname{KKF}(r=0.609)$ and negatively in soils from BCR $(r=-0.318)$. Results show that organic carbon was significantly $(\mathrm{P}=0.05)$ and positively correlated with $\mathrm{B}$ in soils from KKF and CF, but not in those from BCR. The type of association between clay and B obtained in the present study, however, varied between soils from the different parent materials. The combined contribution of the constant, silt, clay and organic carbon was significant $(\mathrm{P}<0.01)$ on $\mathrm{Zn}$ in all the soils. Their relative contributions, represented by $\mathrm{R}^{2}$, were $34.8,40.9$ and $40.2 \%$ in soils developed from BCR, KKF and CF, respectively. The effect on the variables on the regression equation was, however, significant $(\mathrm{P}=0.05)$ for $\mathrm{B}$ in soils developed from KKF only $\left(\mathrm{R}^{2}=32.2 \%\right)$.

Table 2: Distribution of $\mathrm{Zn}$ and B in $0-30 \mathrm{~cm}$ soils developed from BCR, KKF and CF in Bauchi State

\begin{tabular}{lcc}
\hline & $\begin{array}{c}\text { Bn } \\
(\mathrm{mg} / \mathrm{kg})\end{array}$ & $0.13-0.74$ \\
Range & Basement complex rock & 0.38 \\
Mean & $0.40-2.21$ & 41.2 \\
CV (\%) & 1.12 & $0.14-0.69$ \\
& 34.5 & 0.38 \\
Range & Kerri-Kerri formation & 39.9 \\
Mean & $0.24-4.11$ & \\
CV (\%) & 1.50 & $0.16-0.80$ \\
& 61.0 & 0.40 \\
Range & Chad formation & 40.6 \\
Mean & $0.41-2.33$ & \\
CV (\%) & 1.28 & $0.13-0.80$ \\
Overall: & 46.3 & 0.41 \\
Range & & 41.1 \\
Mean & $0.24-4.11$ & NS \\
CV (\%) & 1.26 & \\
\hline LSD (P=0.05) & 50.5 & \\
\hline
\end{tabular}

NS: Not significant

Table 3: Correlation matrix among some physico-chemical properties in soils developed on the three parent materials in Bauchi State, Nigeria

\begin{tabular}{|c|c|c|c|c|c|c|c|}
\hline & & Sand & Silt & Clay & $\mathrm{pH}$ (in water) & Organic C. & Zn \\
\hline \multirow[t]{3}{*}{ Silt } & BCR & $-0.844 * *$ & & & & & \\
\hline & KKF & $-0.979 * * *$ & & & & & \\
\hline & $\mathrm{CF}$ & $-0.922 * *$ & & & & & \\
\hline \multirow[t]{3}{*}{ Clay } & BCR & $-0.379 *$ & -0.169 & & & & \\
\hline & KKF & $-0.948 * *$ & $0.864 * *$ & & & & \\
\hline & CF & $-0.618 * *$ & 0.305 & & & & \\
\hline \multirow[t]{3}{*}{ pH (in water) } & BCR & $-0.293^{*}$ & 0.338* & -0.046 & & & \\
\hline & KKF & -0.243 & -0.306 & -0.126 & & & \\
\hline & $\mathrm{CF}$ & -0.238 & 0.207 & 0.168 & & & \\
\hline \multirow[t]{3}{*}{ Organic C. } & BCR & 0.147 & 0.010 & $-0.285 *$ & -0.191 & & \\
\hline & KKF & 0.303 & -0.310 & -0.266 & -0.021 & & \\
\hline & CF & -0.292 & 0.167 & 0.330 & 0.241 & & \\
\hline \multirow[t]{3}{*}{ Zn } & BCR & 0.060 & $-0.318 *$ & $0.440 * *$ & 0.061 & $-0.410 * *$ & \\
\hline & KKF & $0.602 *$ & $0.609 * *$ & $0.539 *$ & -0.185 & -0.365 & \\
\hline & $\mathrm{CF}$ & 0.276 & -0.093 & $-0.460 *$ & -0.154 & $-0.563 * *$ & \\
\hline \multirow[t]{3}{*}{ B } & BCR & -0.049 & 0.224 & $-0.302 *$ & -0.114 & 0.127 & -0.193 \\
\hline & KKF & 0.299 & -0.327 & -0.229 & 0.189 & $0.471^{*}$ & -0.320 \\
\hline & $\mathrm{CF}$ & -0.278 & 0.060 & $0.524 * *$ & 0.181 & $0.345 *$ & $-0.469 *$ \\
\hline
\end{tabular}

$\mathrm{BCR}=$ Basement complex rock; KKF $=$ Kerri-Kerri formation; $\mathrm{CF}=\mathrm{Chad}$ formation, $*$, ** and $* * *=$ significant at $\mathrm{P}=0.05$ and 0.001 , respectively 


\section{DISCUSSION AND CONCLUSION}

The results from this study indicate a strong influence of parent materials on the clay distribution as earlier reported by Mustapha, et al. (2002). The $\mathrm{pH}$ was more or less uniform and rated moderately acid, while the organic carbon was low.

Results from the present study show that the mean $\mathrm{Zn}$ contents for soils from the parent materials considered and generally for the State are greater than the $0.80 \mathrm{mgZn} / \mathrm{kg}$ critical limit reported by Lindsay and Norvell (1978). This corroborates earlier findings by Mustapha et al. (2002) for soils in the same geo-ecology. It is to be noted, however, that the overall $\mathrm{Zn}$ content ranged (in $\mathrm{mg} / \mathrm{kg}$ ) from 0.24-4.11 indicating that some locations contain $\mathrm{Zn}$ well below the critical level for optimum crop production; and calls for its inclusion in fertilizer formulations for such areas found "low". With mean contents (in $\mathrm{mg} / \mathrm{kg}$ ) of $0.38,0.38$ and 0.40 , respectively for soils developed from BCR, KKF and CF, B toxicity in the soils studied is unlikely, for now.

\section{REFERENCES}

Abdu, N.; Ibrahim, I.; Abdullahi, A.A., (2006). Effects of soil properties on boron sorption in a savanna soil. Idoga, S., Ayuba, S. A., Ali, A., Agede, O. O. and Ojeniyi, S. O. (Eds). Proceedings of the $30^{\text {th. }}$ Annual Conference of the Soil Science Society of Nigeria. 213-220.
Amalu, U.C.; Esu, I.ER.; Nwulu, M.V.N., (2001). Fertility management of some Gleyic Luvisols and Alisols grown to rice in South East Nigeria: Boron, Copper and Zinc status. Ojeniyi, S.O.; Esu, I.E.; Amalu, U.C.; Akamigbo, F.O.R.; Ibanga, I.J.; Raji, B.A. (Eds). Proceedings of the 27 ${ }^{\text {th. }}$ Annual Conference of the Soil Science Society of Nigeria. 150-160.

Bowen, J.E.; Kratky, B.A., (1983). Micronutrients:Soil and climatic conditions often determine micronutrient deficiencies. World Farm., 25, 10-25.

Burrigde, J.C.; Ahn, P.M., (1970). A spectrographic survey of representative Ghana forest soils. J. Soil Sci., 16, 296-309.

Harry, F.; Steven, C.A., (1995). Statistics: Concepts and applications. Cambridge University Press, Great Britain. 853.

Lindsay, W.L.; Norvell, W.A., (1978). Development of DTPA soil test for zinc, iron, manganese and copper. Soil Sci. Soc. Am. J., 42, 421-428.

Mustapha, S.; Singh, B.R., (2003). Available zinc, copper, iron and manganese status of the basement complex rock-derived Ultisols in Bauchi State: A case study. Niger. J. Soil Res., 4,35-40.

Mustapha, S.; Singh, L.; Babaji, G.A.; Saddiq, A.M. (2002). Effects of parent rocks, topographic position and depth on some soil extractable micronutrients. Niger. J. Tropic. Agri., 4, 85-91.

Page, A.L.P.; Miller, R.H.; Keeey, D.R., (1982). Methods of Soil Analysis. Agron. 9, Part 2, ASA, Madison, Wisconsin, U.S.A.

\section{AUTHOR (S) BIOSKETCHES}

Mustapha, S., Crop Production Programme, Abubakar Tafawa Balewa University, P.M.B. 0248, Bauchi, Nigeria, Email: shafiumusty@yahoo.com

Fagam, A. S., Crop Production Programme, Abubakar Tafawa Balewa University, P.M.B. 0248, Bauchi, Nigeria, Email: asfagam@yahoo.com

This article should be referenced as follows:

Mustapha, S., Fagam, A. S., (2007). Influence of parent material on the contents and distribution of B and Zn in upland soils of Bauchi State, Nigeria. Int. J. Environ. Sci. Tech., 4 (3), 359-362. 